\title{
Praktik Mom Shaming Oleh Netizen Indonesia Terhadap Selebritis Yang Melakukan Sharenting Di Media Sosial
}

\author{
Annisa Savira \\ Departemen Ilmu Komunikasi, Universitas Airlangga, Jalan Airlangga 4-6, Indonesia. \\ Email: annisasavira2409@gmail.com
}

\begin{abstract}
A B S T R A C T
This research focuses on analyzing the practice of shaming mothers that occurred on the Instagram accounts of two celebrity mothers, Andien Aisyah and Rachel Vennya. Researchers raised this topic because mom shaming is a phenomenon that often occurs nowadays, but not many have conducted an in-depth investigation of mom shaming so that it affects knowledge and awareness of mom shaming's actions and the impact of mom shaming on a mother. Analysis of the practice of mom shaming is carried out using the textual analysis method, where the researcher interprets the text from the sharenting practices of celebrity mothers on their social media, mom shaming comments by Indonesian netizens in the comments column of their uploads, and also resolutions or feeds. The results of this study indicate that mom shaming is often accepted by celebrity mothers, in this case Andien Aisyah and Rachel Vennya, regardless of the parenting method applied. However, there are differences in mom shaming patterns from sharenting practices or how celebrity mothers are free from parenting on their social media pages regarding the persona of the celebrity mother. The results of this study also show the intention of giving mom shaming text by Indonesian netizens to celebrity mother, where the messages are mom shaming messages that express their thoughts and feelings on their social media pages.
\end{abstract}

Keywords: Textual analysis; social media; cyber bullying; celebrity culture; sharenting

\section{A B S T R A C T}

Penelitian ini merupakan penelitian yang fokus untuk menganalisis praktik mom shaming yang terjadi pada akun Instagram dua ibu selebritis, yaitu Andien Aisyah dan Rachel Vennya. Peneliti mengangkat topik ini karena momshaming merupakan fenomena yang banyak terjadi saat ini, namun belum banyak yang melakukan penelitian secara mendalam mengenai momshaming, sehingga berpengaruh pada kurangnya pengetahuan dan kesadaran terhadap tindakan momshaming dan dampak dari momshaming terhadap seorang ibu. Analisis terhadap praktik momshaming ini dilakukan menggunakan metode analisis tekstual, dimana peneliti menginterpretasi dan memaknai teks baik dari praktik sharenting yang dilakukan ibu selebritis pada media sosialnya, komentarkomentar momshaming oleh netizen Indonesia yang ada pada kolom komentar unggahannya, dan juga resolusi atau umpan balik yang diberikan ibu selebritis dalam menanggapi komentar momshaming yang ia terima.Hasil dari penelitian ini menunjukkan bahwa tindakan momshaming kerap diterima oleh para ibu selebritis, dalam hal ini adalah Andien Aisyah dan Rachel Vennya, terlepas dari bagaimanapun metode parenting yang diterapkan. Namun, terdapat perbedaan pola momshaming dari praktik sharenting atau bagaimana ibu selebritis memunculkan parentingnya pada halaman media sosialnya dan juga persona dari ibu selebriti tersebut. Hasil penelitian ini juga menunjukkan intensi dari diproduksinya teks momshaming oleh netizen Indonesia dimana mayoritas pesan momshaming ditujukan untuk mengekspresikan pikiran dan perasaannya saja terkait parenting yang dimunculkan oleh ibu selebriti pada halaman media sosialnya.

Kata kunci : Analisis Tekstual; Mom Shaming; Media Sosial Instagram.

\section{A. PENDAHULUAN}

Setiap ibu memiliki caranya masing-masing dalam mengasuh anaknya. Terlebih, kini semakin banyak tren dan bentuk-bentuk modern parenting yang hadir dan diperkenalkan kepada para ibu masa kini. (Lazarus, 2015)menyebutkan bahwa gaya dan tren parenting ini senantiasa berevolusi seiring dengan berkembangnya gaya hidup dalam masyarakat. Modern parenting yang dilakukan oleh modern parents (orang tua modern) ini juga berkaitan dengan berperannya internet bagi orang tua dalam mengambil keputusan parenting, seperti yang disebutkan oleh 
(Klass \& Damour, 2017) mengenai modern parenting sebagai berikut: "modern parents have the entire internet at their disposal and don't follow any single authority".

Sebagai fase utama dalam perkembangan anak, masa infancy dan toddler dalam rentang usia 0 hingga 3 tahun ini menjadi fase dimana seorang ibu harus menomor-duakan urusan dirinya. Hal tersebut tidak lain disebabkan karena kehidupan anak pada masa infancy sangat bergantung pada orang tuanya, terutama seorang ibu yang harus memberi ASI, dan melakukan aktivitas nurturing atau pengasuhan lainnya. Selain itu, Leigh dan Milgrom dalam (McDaniel et al., 2012)menyatakan bahwa proses transisi perempuan menuju peran sebagai seorang ibu setelah melahirkan bayi (newborn/infant) merupakan tahap kehidupan yang penuh tekanan karena banyaknya tuntutan substansial yang diajukan bayi tersebut kepada keluarga.

Tak jarang apabila orang tua, terutama para ibu memutuskan untuk mengikuti kelas-kelas parenting dan mempelajari teknik parenting melalui buku petunjuk demi keberhasilan dalam mengasuh anaknya. Disamping untuk menjadikan orang tua merasa lebih tersambung, terlibat, dan terfokus pada anak mereka, mengikuti kelas parenting, membaca buku panduan parenting, dan juga mengunjungi situs web parenting ini diminati oleh orang tua untuk memenuhi ekspektasi peran (role expectations) dan juga memenuhi standar dalam parenting atau yang disebut denganIM (maternal ideals) (Prikhidko \& Swank, 2018).

Standar parenting dalam masyarakat juga didasari oleh kebudayaan masing-masing tempat. (Bornstein, 2012)menjelaskan bahwa selain situasi keluarga dan socioeconomic status (SES), budaya juga menjadi pendorong beragam pola persepsidan praktik parenting. Adanya standar dalam parenting dapat menjadi tekanan bagi seorang ibu, seperti yang dikatakan oleh (Prikhidko \& Swank, 2018), "the life ofa new mother is exacerbated by contemporary maternal ideals, which may cause her to feel guilty for not being a perfect parent". Selain itu, adanya standar parenting atau maternal ideals ini erat kaitannya dengan level amarah yang lebih tinggi, peningkatankadar stress, dan merasa bersalah serta malu (Prikhidko \& Swank, 2018). Sebaliknya, seorang ibu dalam menjalankan proses parenting, selalu membutuhkan dukungan sosial dari lingkungannya (Ngai et al., 2012).

Dukungan sosial disini berkaitan dengan konsep stress mediator, dimana seorang ibu yang mendapatkan dukungan dari lingkungan sekitarnya dapat membuat ibu tersebut lebih tahan terhadap efek buruk stressBeresford dalam (Armstrong et al., 2005).(Narvaez, 2013)menyebutkan bahwa adanya dukungan dari kerabat dankeluarga membantu seorang ibu, terutama ibu baru untuk mengatasi stres dengan lebih baik, dan membantu ibu melihat anak secara lebih positif. Disamping itu, (McDaniel et al., 2012)menyebutkan bahwa dukungan sosial ini erat kaitannya dengan semakin baiknya kesehatan pernikahan, kepuasan dalam hubungan, childoutcomes atau hasil parenting terhadap anak, dan interaksi antara ibu dan anak.

Selain dukungan sosial yang didapatkan oleh seorang ibu dalam keseharian ibu tersebut di dunia nyata, hadirnya teknologi berupa media baru juga memberikan kesempatan bagi seorang ibu untuk terhubung dengan orang lain dengan jangkauan lebih luas dan mendapatkan dukungan sosial melalui internet, yang mungkin tidak dapat ditemui di dunia nyata(McDaniel et al., 2012). Sehingga, tak jarang saat ini ditemui komunitas perkumpulan para ibu di dunia maya, baik dalam situs web, papan pesan, maupun media sosial.

Media online kini membuka ruang bagi para ibu untuk terhubung melalui unggahan-unggahan mereka, mulai dari pengalaman kehamilan hingga pengalaman mengasuh dan mendidik anak tersebut seiring dengan perkembangannya. Para ibu juga dapat menanggapi, menandai, maupun membagikan unggahan satu sama lain di media sosial seperti Instagram. Aktivitas membagikan unggahan parenting ke media sosial ini disebut dengan sharenting.(Verswijvel et al., 
2019)mendefinisikan sharenting sebagai tindakan membagikan informasi baik berupa foto, video, maupunstatus mengenai anaknya di situs jejaring sosial (social network sites). (Lupton et al., 2016)memaparkan hasil penelitian sosial bahwa para ibu menggunakan media sosial untuk menemukan peluang bertemu para ibu lainnya yang tinggal berdekatan, untuk mengurangi perasaan terisolasi dan bosan, serta untuk berbagi dukungan dan informasi khususnya bagi ibu dengan anak berkebutuhan khusus.

Dengan semakin besarnya penggunaan media sosial di kalangan para ibu dan semakin populernya budaya sharenting, khususnya Instagram, kini platform tersebut tak hanya digunakan untuk mengunggah konten parenting secara personal saja, melainkan juga digunakan untuk membentuk citra sekaligus menjadikan ibu tersebut sebagai sosok influencer atau sosok yang memiliki pengaruh yang kuat dalam membagikan pengalaman, tips, dan cara-cara dalam parenting.

Sebagai salah satu objek dari penelitian ini, Andien Aisyah merupakan salah satu ibu selebritis dengan cara mendidik anak yang berbeda dengan mayoritas ibu pada umumnya. Andien memilih untuk mengasuh dan mendidik anaknya, Kawa, dengan cara-cara alami untuk mewujudkan kecerdasan naturalis (naturalistintelligence), seperti melahirkan dengan metode water birth dan lotus birth, penerapan baby-led weaning (BLW), kebiasaan earthing atau grounding dengan bertelanjang kaki, dan lain sebagainya. Andien sebagai public figure atau seseorang yang dikenal oleh masyarakat luas, seringkali dikritik mengenai caraparentingnya yang dianggap tidak semua anak bisa diperlakukan seperti Andien memperlakukan Kawa. Sebagian besar bentuk kritik dan komentar mengandung unsur kata-kata yang terkesan menggurui dan merendahkan caraparenting Andien, serta mencoba untuk mengontrol bagaimana seharusnya ia mengasuh anaknya. Hal inilah yang disebut dengan mom shamingmenurut Kenney dalam (Cabotaje, 2018).

Mom shaming ini hadir diantaranya disebabkan oleh perbedaan cara asuhantara ibu satu dengan yang lainnya, maupun perbedaan pandangan terhadap cara asuh yang dianggap benar. (Villines, 2017)mendefinisikan mom shaming sebagai tindakan mengkritik pilihan seorang ibu dalam mengasuh anak, tanpa mempertimbangkan atau mengetahui faktor-faktor dibalik pilihan tersebut seperti peran ayah, pengasuh lain, faktor budaya, atau kondisi finansial. Definisi momshaming menurut Villines ini juga menyebutkan bahwa mom shaming dapatmenimbulkan adanya label "bad mothers" atau ibu yang tidak baik.

Mom shaming berpotensi untuk mempengaruhi kondisi psikologis seorang ibu.Seorang ibu yang menerima kritik dan komentar secara terus menerus akan mempertanyakan kemampuan cara asuhnya. (Preidt, 2017)mengatakan bahwa dampak yang dirasakan seorang ibu setelah menerima perilaku mom shaming adalah ibu yang merasa tidak yakin dengan kemampuan parentingnya.

Mom shaming bisa datang kapanpun dan dilakukan oleh siapapun, bahkanoleh orang asing. Mom shaming juga bisa dilakukan baik di publik, secara privat, maupun online. Faktanya, saat ini mom shaming kerap kali terjadi dan menjadi hal yang umum terjadi dalam dunia parenting, terlebih sejak munculnya Internet dan media sosial. Kehadiran media sosial membuat kepentingan seseorang kini menjadi kepentingan publik. Instagram adalah salah satu media sosial dimana banyak ditemui tindakan mom shaming berupa komentar dalam unggahan seorang ibu. (Lane, 2017) berpendapat bahwa saat ini, melakukan tindakan mom shaming adalah semudah mengetuk tombol 'komentar' dalam media sosial Instagram. Hal ini tentu berlaku pula bagi para ibu selebritis yang mengunggah gambar-gambar seputar kehidupannya, termasuk aktivitas parenting, ke dalam Instagram. 
Penelitian mengenai fenomena mom shaming ini dilakukan dengan mengamati konten-konten yang berkaitan dengan aktivitas parenting pada dua akun Instagram ibu selebritis (celebrity mom) yang melakukan aktivitas sharenting, yaitu Andien Aisyah dan Rachel Vennya. Dirujuk dari jurnal (O'Brien Hallstein, 2011), ibu selebritis atau celebrity mom dipahami sebagai sosok ibu yang menjadi sorotan banyak orang dan membawa pengaruh besar bagi pengikutnya.

Banyaknya tindakan mom shaming yang dialami oleh ibu selebriti oleh netizen Indonesia pada halaman media sosialnya melatar belakangi pemilihan topik penelitian ini, dimana akan dianalisis bagaimana pola mom shaming pada media sosial ini berdasarkan praktik sharenting para ibu selebritis, dalam hal ini adalah Andien Aisyah dan Rachel Vennya, praktik mom shaming oleh netizen Indonesia pada kolom komentar unggahan ibu selebriti, dan juga resolusi atau umpan balik dari para ibu selebriti dalam menanggapi komentar mom shaming yang mereka terima. Maka dari itu, pernyataan utama peneliti adalah bagaimana praktik mom shaming yang dilakukan oleh netizen Indonesia terhadap ibu selebritis yang melakukan sharenting di halaman media sosial.

\section{B. HASIL DAN PEMBAHASAN}

Untuk mengeksplorasi praktik mom shaming di media sosial, peneliti memilih untuk meneliti pada kolom komentar dua akun Instagram ibu selebritis, yaitu Andien Aisyah (@andienaisyah dan @andienippekawa) dan Rachel Vennya (@rachelvennya). Alasan pemilihan dua akun ibu tersebut adalah karena perbedaan cara asuh yang diterapkan, dimana Andien menerapkan cara asuh yang tidak umum dan kontroversial di Indonesia seperti penerapan baby-led weaning (BLW) sebelum waktunya dan membiasakan anaknya untuk barefoot di luar ruangan, sedangkan Rachel menerapkan cara asuh yang tidak jauh berbeda dengan cara asuh para ibu pada umumnya di Indonesia, namun keduanya tetap mendapat tindakan mom shaming di kolom komentar Instagramnya.

Peneliti menganalisis praktik mom shaming berdasarkan isu-isu parenting yang dibagikan oleh ibu selebriti pada halaman media sosialnya. Beberapa isu parenting yang diunggah Andien Aisyah yang menerima komentar mom shaming meliputi antara lain sebagai berikut: penerapan baby-led weaning (BLW), penerapan mouth taping, kebiasaan barefoot, perkembangan anak, dan hubungan ibu dan anak. Sedangkan isu parenting yang menerima komentar momshaming pada akun Instagram Rachel Vennya adalah mengenai mengatasi anak yang cedera dan menertawakan anak.

\section{Mom Shaming terhadap Penerapan Baby-Led Weaning}

Pada isu penerapan metode babyled-weaning atau BLW oleh Andien, Andien mendapatkan kritik karena memulai program BLW pada anaknya, Kawa, yang dianggap masih terlalu dini untuk menerapkan metode makan ini. Andien juga kerap dikritik karena memberikan makanan padat dan utuh seperti kelengkeng yang belum dipisahkan terlebih dahulu dari bijinya. Penerapan metode ini dikhawatirkan dapat menyebabkan anak tersedak. Pada salah satu unggahannya, Andien menampilkan konten mengenai penerapan BLW ini disertai dengan caption yang mengimbau orang tua lain untuk mempercayai naluriah anak dalam memberikan makanan. Hal ini kemudian menuai kontroversi mengetahui bahwa tidak semua anak dapat diperlakukan sebagaimana Andien memperlakukan anaknya mengingat hal tersebut memiliki potensi untuk menjadi berbahaya. 


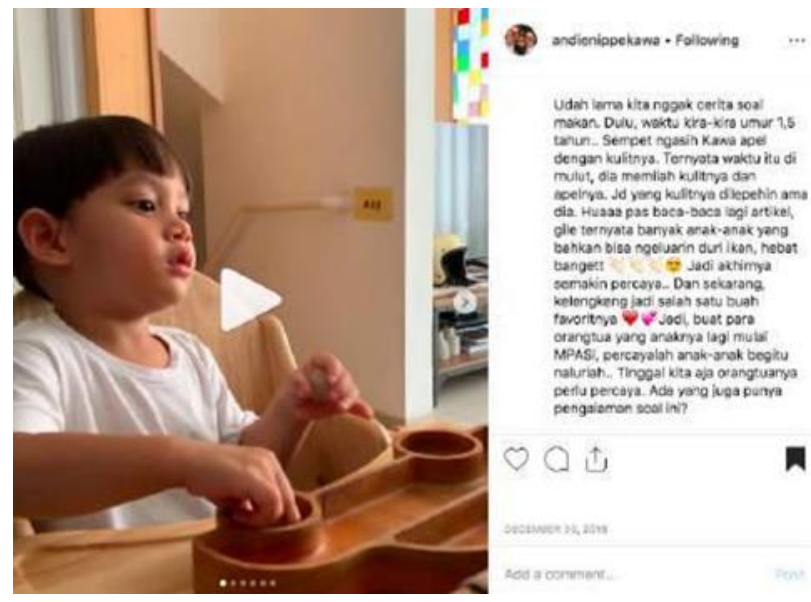

Sumber: Akun Instagram Andien Aisyah

Gambar 1. Unggahan BLW Pada Akun Instagram Andien Aisyah (@andienippekawa)

Komentar mom shaming terhadap isu ini mengindikasikan bahwa apa yang menjadi isu hingga memunculkan tindakan mom shaming ini adalah praktik sharenting Andien atau bagaimana Andien menampilkan cara asuhnya yang riskanmenjadi seolah-olah dapat diterapkan oleh semua orang tua melalui unggahan-unggahannya dan pernyataan yang ia tulis pada captionnya. Pola mom shaming oleh netizen Indonesia juga dapat diindikasikan pada kolom komentar unggahan ini seperti penggunaan frasa "heimlich maneuver" sebagai kata ganti "tersedak" yangmengindikasikan bahwa orang-orang yang mengkritik cara asuh Andien adalah orang yang memiliki pengetahuan terkait metode parenting dari luar negeri.

\section{Mom Shaming terhadap Praktik Mouth Taping}

Praktik mouth taping dilakukan Andien dengan memplaster mulut anak di malam hari ketika tidur, tujuannya adalah untuk membawakan manfaat-manfaat yang baik bagi tubuh dengan menghirup udara pada jumlah yang efektif. Namun demikian, Dr. Yaremchuk dalam (Nagesh, 2019)menyebutkan bahwa disamping manfaat yang dirasakan dari mouth taping, hal ini tetap akan menjadi berbahaya apabila diterapkan pada anak-anak. Memplaster mulut anak ketika tidur dikhawatirkan akan memunculkan potensi tersedak apabila anak tersebut ingin mengeluarkan sesuatu dari mulut seperti muntah. Respon negatif terhadap tindakan Andien yang melakukan mouth taping pada anak ini dipicu oleh beberapa faktor, antara lain adalah: teknikpernapasan buteyko ini masih belum banyak dikenal dan diterapkan di budaya Indonesia, Andien yang sejak memiliki anak menjadi sosok kontroversial terhadap pilihan parentingnya, dan beberapa literatur yang menyebutkan bahwa pernapasan buteyko tidak memberikan dampak positif dan justru berbahaya. 


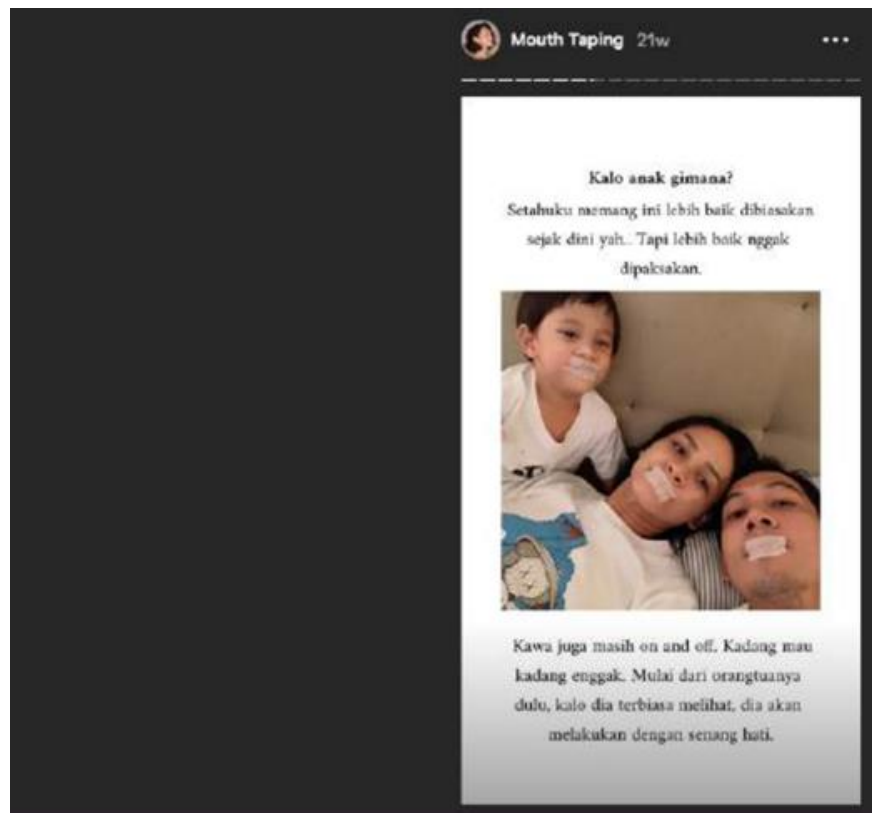

Sumber: Akun Instagram Andien Aisyah

Gambar 2. Unggahan Mouth Taping Pada Akun Instagram @andienaisyah

Ditinjau dari komentar-komentar mom shaming yang diterima Andien terkait isu mouth taping ini, diketahui bahwa apa yang menjadikan Andien menerima komentar mom shaming adalah karena penerapan metode buteyko breathing yang iaterapkan dengan memplaster mulut kepada anaknya itu sendiri, dimana hal tersebut dianggap berbahaya mengetahui resiko yang dapat dialami oleh anak usia dini ketika mulutnya diplaster saat tidur dapat berujung fatal. Disamping itu, aktivitas membagikan pengalaman dan pengetahuan terkait mouth taping ini juga ditentang oleh para komentator dikarenakan Andien sebagai public figure memiliki peran yang signifikan dalam mempengaruhi audiensnya untuk mengikuti metode parenting yang diterapkannya.

Pada salah satu komentar, komentator menyebutkan parenting yang dibagikan Andien ke halaman media sosialnya sebagai pseudosain atau ilmu semu karena aktivitas mouth taping sebagai aplikasi dari metode pernapasan buteyko sendiri dianggap sebagai sesuatu yang masih diperdebatkan efektivitasnya, bahkan dikatakan sebagai sesuatu yang berbahaya apabila diaplikasikan pada anak berusia dini. Disamping itu, penggunaan istilah bahasa asing seperti "pseudoscience" juga mengindikasikan pola pelaku mom shaming oleh netizen Indonesia dimana komentator memiliki kecenderungan untuk menggunakan bahasa asing seperti yang dilakukan Andien dalam merujuk cara asuhnya.

\section{MomShaming terhadap Kebiasaan Barefoot}

Komentar-komentar mom shaming lain ditemukan pada unggahan Andien yang mengangkat konten tentang kebiasaan barefoot atau telanjang kaki yang diterapkan pada Kawa. Andien menerapkan kebiasaan barefoot kepada Kawa sejak dini karena hal tersebut dikatakan membawakan dampak positif untuk perkembangan anak dan menumbuhkan "kecerdasan naturalis" pada anak. 


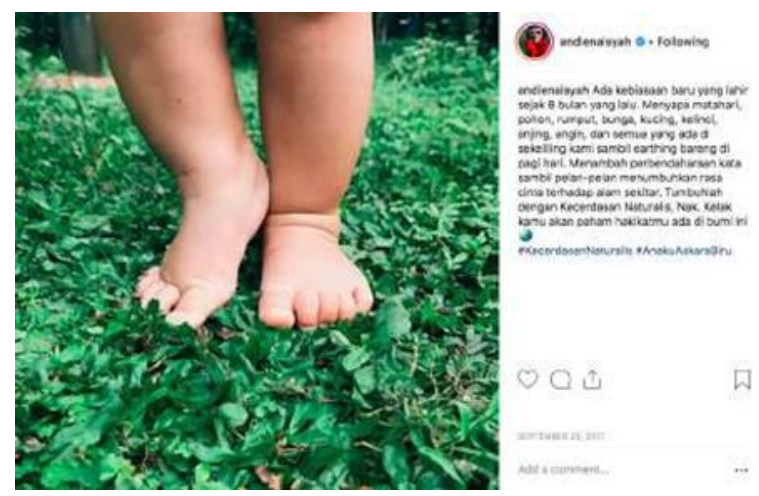

Sumber: Akun Instagram Andien Aisyah

Gambar 3. Unggahan Barefoot Pada Akun Instagram @andienaisyah

Mengetahui seringnya Andien menerapkan barefoot atau membiarkan Kawa beraktivitas tanpa menggunakan alas kaki, banyak ditemui akun-akun yang mengkritik Andien pada akun Instagramnya karena alasan kebersihan, kesehatan, dankelayakan. Dari bagaimana komentar mom shaming dituliskan, diketahui bahwa apa yang menjadikan Andien mendapatkan komentar mom shaming ini adalah bagaimana Andien memunculkan kebiasaan barefoot pada anak ini seolah-olah merupakan hal baru yang jauh dari kebudayaan di Indonesia dengan merujuk pada kebiasaan bertelanjang kaki ini dengan istilah "barefoot", "grounding", dan "earthing". Padahal pada realitanya, seringkali kita ketahui anak-anak di Indonesia seringkali menerapkan budaya telanjang kaki ini atau disebut dengan "nyeker" dalam Bahasa Jawa. Hal ini merupakan bentuk cultural distancing oleh Andien sebagai ibu selebritis di halaman media sosialnya dimana cultural distance atau jarak budaya ini dipahami sebagai perbedaan nilai dan gaya komunikasi yang berakar pada budaya, atau tingkat ketidaksamaan antara dua budaya. Jarak ini muncul ketika individu atau kelompok merasakan bahwa nilai-nilai dan gaya komunikasi mereka berbeda dengan yang lain (Tran et al., 2017).

Disamping itu, dimunculkannya kebiasaan barefoot pada anak oleh Andien dengan embelembel "berdasarkan literatur", "kecerdasan naturalis", dan istilah-istilah bahasa asing yang ia gunakan untuk merujuk pada kebiasaan ini memunculkan kecenderungan bagi audiensnya untuk mengomentari hal ini. Intensitas Andien dalam mengunggah unggahan terkait kebiasaan barefoot Kawa ini juga memicu komentar-komentar mom shaming pada akun Instagramnya. Kawa memang sering dimunculkan Andien tengah beraktivitas tanpa menggunakan alas kaki tak hanya di medan-medan seperti rumput, dan ruangan terbuka lainnya yang umumnya digunakan untuk earthing atau grounding, namun juga di tempattempat umum seperti mall, playground, dan lain-lain.

Komentator-komentator mom shaming terkait isu barefoot Andien disini juga memiliki kecenderungan untuk secara ekspresif mengkritik dan mengomentari hal-hal personal Andien yang ia yakini sebagai hal yang benar, seperti penerapan barefoot dan keputusan Andien untuk memilih sepatu barefoot dibandingkan sepatu bersol, dimana hal tersebut seharusnya menjadi hak Andien. Kecenderungan komentator untuk mengkritik hal-hal dan pilihan personal ibu selebritis disini juga mengindikasikan pola pelaku mom shaming oleh netizen Indonesia. 


\section{Mom Shaming terhadap Isu Perkembangan Anak}

Perkembangan pada anak kerap menjadi isu yang banyak dialami oleh para ibu. Hal ini dikarenakan anak pada usia 0 hingga 5 tahun mengalami pertumbuhan yangpesat. Setiap anak pada tiap tahap perkembangan ini mengalami proses yang berbeda antara satu dengan yang lainnya. Hal ini dikarenakan pertumbuhan manusia sangat individual dan tergantung pada alam dan pemeliharaan (nature and nurture), gen, dan lingkungan (Jax, 2017). Pada kolom komentar dalam beberapa unggahan akun Instagram Andien, ditemui beberapa komentar yang menyinggung tentang perkembangan Kawa, yaitu meliputi perkembangan fisik dan perkembangan bahasa Kawa.

Komentar terkait perkembangan fisik meliputi pertumbuhan gigi Kawa yang dianggap terlambat tumbuh dibandingkan anak-anak lain seusianya. Padahal, disebutkan oleh (DiMaggio \& Cernigliaro, 2019)bahwa ada banyak variasi mengenai kapan gigi pertama pada anak mulai muncul, beberapa bayi juga mungkin belum memiliki gigi pada ulang tahun pertama mereka. Sedangkan untuk komentar negatif mengenai perkembangan bahasa anak ditemukan pada unggahan dengan caption yang menceritakan pengalaman kesalahpahaman Kawa dalam mengartikan kata "Dover" menjadi "rollover". Menurut komentator, caption Andien tersebut hanya dibuat-buat oleh Andien untuk mengesankan bahwa Kawa sudah cukup pintar untuk memahami kata "rollover".

Ketika perkembangan pada anak yang sifatnya bervariasi ini membuat orang lain memiliki kecenderungan untuk melontarkan komentar, maka masalah berada pada komentator dimana komentator merasa perlu untuk menyatakan hal yang seharusnya tidak perlu untuk dikatakan, dalam hal ini mengomentari pertumbuhan gigi anak yang dianggap terlambat dalam kolom komentar seorang ibu yang mengunggah aktivitas makan anak. Hal ini menunjukkan bahwa komentator disini hanya ingin menyampaikan atau mengekspresikan apa yang menurutnya adalah hal yang ganjil.

\section{Mom Shaming terhadap Isu Hubungan Ibu dan Anak}

Hubungan ibu dengan anak merujuk pada keterikatan yang terjalin antara ibu dan anak pada saat anak berusia dini. Disamping kerap menjadi isu yang dipermasalahkan oleh para ibu, isu mengenai hubungan orang tua dan anak juga menjadi salah satu isu mom shaming yang ditemui pada halaman akun Instagram Andien, beberapa diantaranya ditemui pada unggahan sebagai berikut.

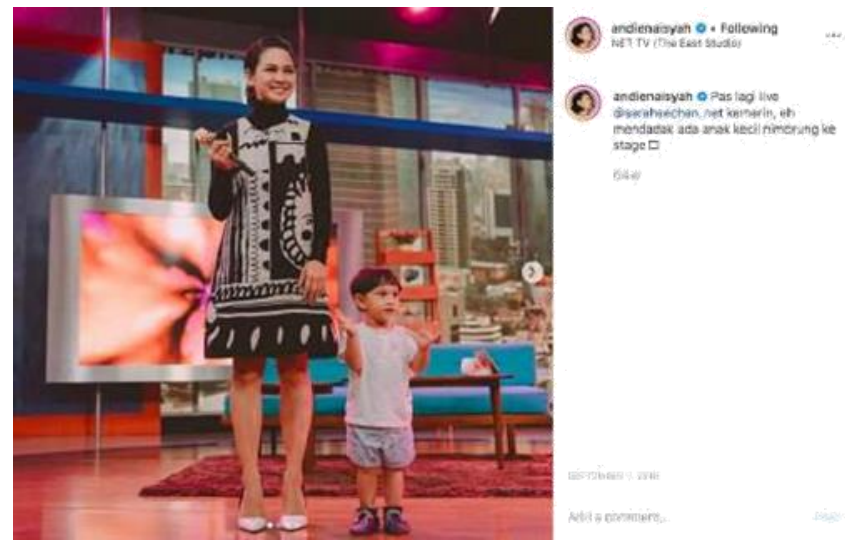

Sumber: Instagram Andien Aisyah

8 
Gambar 4. Unggahan dengan Komentar tentang Hubungan Ibu dan Anak Pada Akun Instagram @andienaisyah

Para komentator dalam unggahan Andien ini memahami bahasa tubuh Kawa yang ditampilkan pada unggahan tersebut sebagai bentuk kebingungan dan ketidak nyamanan yang dirasakan Kawa terhadap situasi yang ia hadapi dalam unggahan tersebut, yaitu berada di atas panggung dan menjadi sorotan banyak orang. Komentar lain mengasumsikan ketidak selarasan interaksi yang terjalin antara Andien dengan Kawa pada unggahan tersebut sebagai tidak adanya chemistry diantara keduanya. Andien sebagai ibu diharapkan oleh para komentator untuk senantiasa memberikan rasa aman pada anak, sekalipun ketika dihadapkan pada situasi yang baru. Komentar-komentar negatif yang mengangkat isu terkait hubungan Andien dan Kawa dalam unggahan ini merupakan bentuk tidak terpenuhinya ekspektasi komentator kepada Andien sebagai ibu untuk selalu memberikan rasa aman dan nyaman pada anaknya.

Komentator melalui komentar mom shaming dalam unggahan ini merendahkan peran Andien sebagai ibu untuk selalu memberikan rasa aman dan nyaman terhadap anaknya. Kecenderungan untuk mengkritik terkait hubungan ibu-anak diantara keduanya berdasarkan pendapat pribadi dari apa yang ditafsirkan melalui gambar dalam unggahan tersebut menjadikan kedua komentator disini memproduksi pesan dengan cara ekspresif dimana pesan digunakan sebagai medium untuk mengekspresikan pikiran dan perasaannya saja, dalam hal ini adalah hubungan ibu-anak Andien dan Kawa yang dianggap tidak selaras.

\section{Mom Shaming terhadap Isu Mengatasi Anak Cedera}

Rachel Vennya dalam salah satu unggahannya sempat menerima kritik karena ia membiarkan Biru menangani rasa sakitnya terlebih dahulu setelah ia mengalami cedera yang dimunculkan pada unggahan sebagai berikut:

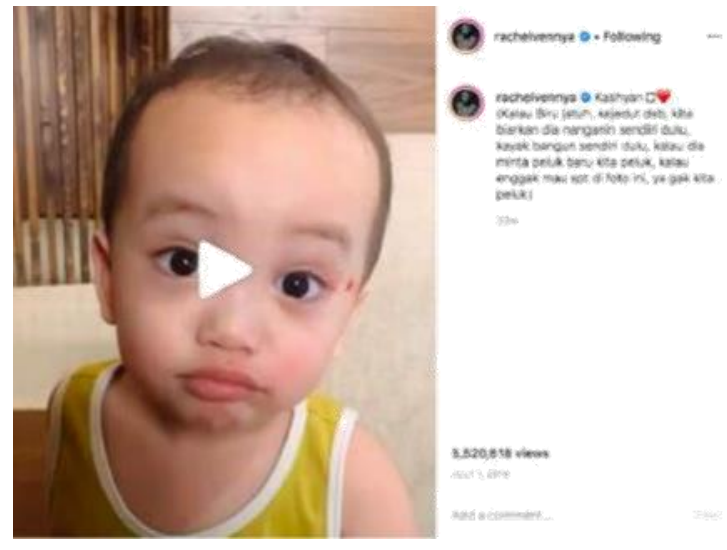

Sumber: Akun Instagram Rachel Vennya

Gambar 5. Unggahan tentang Cedera Anak Pada Akun Instagram @ rachelvennya

Dalam unggahan tersebut, Rachel juga menuliskan caption yang mengatakan bahwa ketika Biru sedang mengalami cedera, ia membiarkannya menangani cedera terlebih dahulu baru kemudian memeluk Biru apabila ia meminta pelukan. Para komentator mempermasalahkan tidak tampaknya tindakan pertolongan pertama dari Rachel yang seharusnya diberikan apabila anak mengalami luka akibat cedera. Namun demkinan, setiap orang tua memiliki caranya sendiri dalam mengatasi situasi-situasi seperti ketika anak mengalami cedera. Dituliskan dalam caption pada unggahan tersebut bahwa cara Rachel merespon cedera yang dialami anak adalah dengan 
membiarkan anak mengalami hal tersebut dengan sendirinya, dengan cataan bahwa cedera yang dialami bukan cedera yang parah, dimana dalam caption tersebut diungkapkan melalui frasa "Kalu Biru jatuh, kejedut, dsb" yang merujuk pada cedera ringan yang dapat ditangani melalui home remedies (penanganan di rumah).

Yang menjadi permasalahan adalah standar ringan atau tidaknya cedera yang dialami anak menurut perspektif komentator dan Rachel, dimana terbentur hingga memunculkan bercak darah pada pelipis anak dianggap komentator sebagai cedera tidak ringan yang seharusnya mendapatkan pertolongan pertama. Namun, Rachel menganggap hal tersebut adalah cedera ringan dimana Biru masih bisa menahan rasa sakit dan tidak meminta pertolongan dari orang tuanya. Hal inilah yang memicu terjadinya mom shaming, ditambah karakteristik para komentator yang memiliki kecenderungan untuk menyerang sesuatu yang dipandang sebagai hal yang salah.

\section{Mom Shaming terhadap Isu Menertawakan Anak}

Selain isu menghadapi anak ketika cedera, komentar mom shaming yang menyinggung isu tentang menertawakan anak juga ditemui pada salah satu unggahan Rachel di akun Instagramnya sebagi berikut:

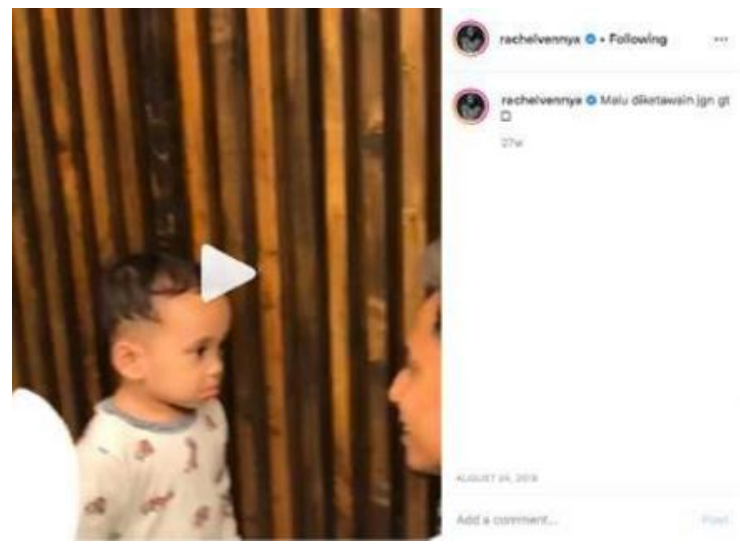

Sumber: Akun Instagram Rachel Vennya

Gambar 6. Unggahan dengan Komentar tentang Menertawakan Anak Pada Akun Instagram @ rachelvennya

Unggahan tersebut menayangkan Biru yang tengah menjadi sorotan orang-orang di sekitarnya. Dalam video tersebut, Biru menampakkan raut muka yang sedih, cemberut, menahan tangis. Selain itu, video tersebut juga menampakkan orang lain yang sedang merekam Biru dan terdengar suara tawa orang-orang terhadap Biru. Pada akhir video tersebut, Biru menghampiri dan memeluk ayahnya, kemudian menangis.

Komentar mom sahming yang ditemukan pada unggahan ini menyerang Rachel yang memunculkan Biru sebagai sorotan dalam unggahan tersebut, dimana tindakan ini dianggap membuat anak merasa tidak nyaman. Di samping itu, komentator lain mengkritik tindakan Rachel dengan merujuk pada pengalaman pribadinya, dimaan menertawakan anak dapat emmiliki dampak jangka panjang yang menyebabkan anak menjadi malu untuk mengekspresikan dirinya. Walaupun demikian, kecenderungan para komentator untuk menuangkan pikirannya dengan menuliskan komentar yang menyatakan keyakinannya terkait perasaan Biru dan 
bagaimana tindakan Rachel dalam unggahan ini akan berdampak pada Biru menjadikan komentar ini sebagai bentuk mom shaming.

\section{Resolusi}

Resolusi yang dimaksud disini adalah bagaimana Andien Aisyah dan Rachel Vennya selaku korban mom shaming merespon komentar mom shaming yang ia dapatkan terhadap beberapa isu parenting yang telah disebutkan sebelumnya. Resolusi Andien Aisyah dan Rachel Vennya terhadap komentar mom shaming dianalisis dan dikategorikan dalam karakteristik korban cyberbullying (pasif dan atau defensif).

Walaupun Andien kerap mendapati komentar mom shaming mengenai metode parenting yang ia terapkan, namun jarang ditemui respon Andien berupa balasanterhadap komentar mom shaming dalam unggahan-unggahan Instagramnya. Berdasarkan wawancara eksklusif Andien dengan Popmama hal tersebut dikarenakan pandangan Andien terhadap parenting yang dianggap personal, sehingga dirasa tidak perlu memberikan dan menanggapi komentar negatif perihal parenting dari orang lain(Ulfah, 2019). Selain itu, Andien menyatakan bahwa dibandingkan menanggapi komentar negatif mengenai parentingnya (mom shaming), ia lebih memilih untuk fokus pada apa yang ia lakukan dan percayai. Selain itu, cara Andien dalam menanggapi komentar-komentar mom shaming lainnya adalah dengan mematikan dan membatasi komentar pada beberapa unggahannya. Salah satu unggahan pada akun Instagram Andien yang sempat menuai banyak kritik dan komentar mom shaming, kemudian diputuskan untuk dinon-aktifkan fitur komentarnya sehingga seluruh komentar yang sudah ada tersembunyi dan tidak ada akun lain yang dapat mengomentari unggahan tersebut. Hal tersebut dilakukan untuk meminimalisir tindakan mom shaming yang ia terima dalam kolom komentar unggahannya. Hal ini menjadikan Andien sebagai korban mom shaming dengan karakteristik pasif.

Berbeda dengan Andien, dalam menanggapi komentar-komentar dalam kolom komentar Instagramnya, termasuk terhadap komentar mom shaming, Rachel memilih untuk melakukan penjelasan atau klarifikasi melalui unggahan baik pada feed maupun Instastory. Salah satu unggahan Rachel yang disertai dengan caption penjelasanmengenai parentingnya dimunculkan pada unggahan sebagai berikut:

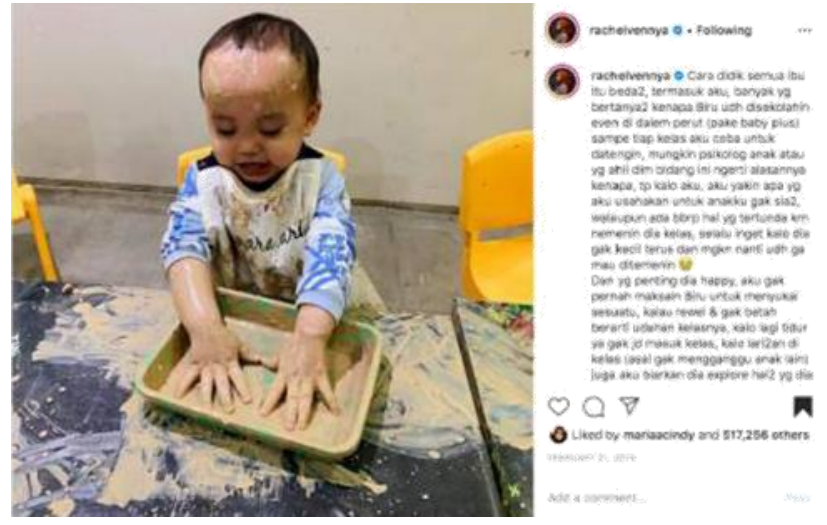

Sumber: Akun Instagram Rachel Venya

Gambar 7. Resolusi Rachel Vennya di Akun Instagram @ rachelvennya

Dalam caption unggahan tersebut, Rachel menuliskan kalimat "cara didiksemua ibu itu bedabeda, termasuk aku" untuk menjelaskan mengenai pilihan parentingnya yang ia terapkan pada 
Biru. Rachel melalui unggahan tersebut jugamenyatakan bahwa bagaimanapun cara dan pilihan parenting yang ia lakukan saat ini, tujuannya tak lain adalah memberikan yang terbaik untuk anaknya dimana hal tersebut merupakan bentuk pembelaan Rachel terhadap beberapa pilihan parentingnya yang menuai kritik. Hal ini menjadikan Rachel memiliki karakteristikkorban mom shaming defensif. Disamping itu, Rachel dalam wawancaranya bersama Tasya Farasya di YouTube pada 20 Maret 2020 menyatakan bahwa ia lebih memilih untuk menghindari mengunggah konten-konten parenting yang bersifat sensitif seperti perihal makanan anak(Farasya, 2020). Hal tersebut dilakukan untuk menghindari kritik atau komentar negatif dan menghindari ibu-ibu lain yang mengikuti parenting tersebut tanpa panduan dari pediatri atau dokter anak.

\section{PENUTUP}

Hasil penelitian ini menunjukkan bahwa tindakan mom shaming atau kritik mengenai cara asuh seorang ibu kerap dialami oleh Andien dan Rachel sebagai seorang ibu selebritis pada akun Instagramnya, terlepas dari bagaimana metode parenting yang diterapkan oleh kedua ibu tersebut. Namun demikian, Andien yangmemang dikenal dengan penerapan metode parenting yang kontroversial mendapat lebih banyak komentar mom shaming pada kolom komentar akun Instagramnya dibandingkan Rachel yang menerapkan parenting yang umum diterapkan di Indonesia.

Hasil analisis mengenai tindakan mom shaming pada kolom komentar akun Instagram Andien dan Rachel menunjukkan bahwa praktik sharenting ibu selebritis atau bagaimana ibu selebritis memunculkan anaknya atau aktivitas parentingnya di media sosial mempengaruhi pola pelaku mom shaming pada kolom komentar akun Instagramnya. Andien dalam praktik sharenting pada halaman media sosialnya memunculkan dirinya sebagai sosok trendsetter dalam metode-metode parenting, sehingga cara penyampaiannya pun lebih terkesan seperti ia mengetahui benar dan meyakini apa yang ia lakukan sebagai hal yang benar. Disamping itu, Andien juga terus-menerus memunculkan hasil dari parenting yang ia terapkan hingga saat ini, seperti Kawa yang sudah pandai memakan makanannya sendiri tanpa mengalami GTM (Gerakan Tutup Mulut) sebagai hasil dari praktik baby-led weaning yang ia terapkan sejak Kawa berusia 5 bulan sehingga hal ini menjadi bukti yang meyakinkan bahwa apa yang diterapkan Andien dapat diterapkan pula oleh audiensnya. Hal ini memicu kritik perihal bagaimana Andien memunculkan parentingnya di halaman media sosialnya yang begitu meyakinkan sehingga dianggap komentator mengkhawatirkan apabila praktik parenting tersebut diterapkan oleh para ibu audiens Andien. Andien juga menerima kritik karena praktik cultural distancing dimana bagaimana ia memunculkan metode parenting yang ia terapkan seolah-olah jauh dari budaya Indonesia menggunakan istilah-istilah bahasa asing seperti baby-led weaning,barefoot, mouth-taping dan lain sebagainya. Disamping itu, beberapa komentar jugasecara langsung mengkritik beberapa metode parenting Andien yang dianggap membahayakan anaknya.

Sebaliknya, Rachel yang memunculkan parenting yang lebih umum diterapkan di Indonesia dan jarang memunculkan unggahan-unggahan yang kontroversial seperti metode makan anak dan lain sebagainya, terhitung jarang menerima komentar momshaming. Beberapa komentar mom shaming yang Rachel terima pada kolom komentarunggahannya hanya merupakan komentar yang mencari celah kesalahan pada tindakan Rachel, bukan komentar yang mengkritik metode parenting Rachel secara umum. Perbedaan praktik sharenting terlihat jelas diantara 
kedua ibu selebritis ini dimana Rachel lebih memilih untuk "main aman" dengan menghindari unggahan yang bersifat kontroversial dan mengundang kritik dari audiensnya.

Selain perbedaan terhadap apa yang menjadi isu hingga memunculkan komentar mom shaming, perbedaan jumlah komentar juga menunjukkan perbedaan pola mom shaming pada akun Instagram Andien Aisyah dan Rachel Vennya. Andien Aisyahmenerima total sekitar 200300 komentar per unggahannya dan mendapatkan komentar mom shaming sebanyak 7-19 komentar, sedangkan Rachel bisa mendapatkan total sebanyak 6000 komentar namun hanya ditemukan 2-4 komentar mom shaming pada unggahannya. Hal ini menunjukkan bahwa persona ibu selebritisdan bagaimana praktik sharenting ini dimunculkan pada akun media sosialnya membentuk pola mom shaming yang berebeda pula.

Berdasarkan analisis terhadap cara produksi pesan komentator mom shaming, komentar mom shaming pada akun Instagram Andien Aisyah dan Rachel Vennya didominasi oleh komentar dengan cara produksi pesan ekspresif (expressive designlogic) dimana hal ini menunjukkan bahwa komentar mom shaming oleh netizenIndonesia disini menuliskan komentar hanya untuk mengekspresikan perasaan dan pikirannya saja melalui pesan yang dituliskan dengan terbuka dan cenderung mengabaikan perasaan komunikan selaku penerima pesan yaitu ibu selebritis. Dari beberapa komentar yang dianalisis, hanya dua yang menuliskan komentar dengan cara produksi pesan konvensional, dimana pesan disampaikan dengan pemilihan kata yang baik dan terstruktur dengan tujuan agar pesan yang dituliskan dapat diterima oleh komunikan.

Dalam menghadapi komentar mom shaming pada kolom komentar akun Instagramnya, kedua ibu selebritis ini memiliki cara yang berbeda. Andien lebih bersifat pasif dan tidak menanggapi komentar mom shaming yang ia terima pada akun Instagramnya. Andien juga lebih memilih untuk menonaktifkan fitur komentar pada beberapa unggahan yang mendapat komentar mom shaming. Hal tersebut dikarenakan Andien menganggap bahwa parenting adalah hal yang personal sehingga dirasa tidak perlu untuk menanggapi kritik dan komentar dari orang lain. Berbeda dengan Andien, Rachel bersifat defensif dalam menanggapi komentar mom shaming. Dalam salah satuunggahannya, ia menuliskan penjelasan mengenai pilihan parenting yang ia jalankan dan menyatakan bahwa keputusan parenting tiap ibu adalah berbeda-beda. Hal tersebut merupakan pembelaan Rachel terhadap komentar-komentar yang menyinggung dan mengkritik mengenai cara asuhnya yang dimunculkan di Instagram.

Mayoritas pelaku mom shaming pada kolom komentar unggahan Andien dan Rachel ditinjau dari profil komentator adalah seorang wanita, beberapa diantaranya adalah seorang ibu. Hal tersebut diketahui diantaranya dari foto profil pemilik akun, username akun, keterangan atau biografi akun, dan unggahan pada akun Instagramkomentator. Hal tersebut menunjukkan bahwa tindakan mom shaming atau mengkritik seorang ibu datangnya dari seorang wanita, bahkan dari seorang ibu pula. Namun demikian, perlu diketahui bahwa identitas dalam media sosial bisa dimanipulasi dan seseorang bisa menjadi siapapun tanpa memunculkan identitas aslinya.

Selain itu, beberapa akun tanpa identitas juga ditemukan sebagai pelaku momshaming pada kolom komentar akun Andien dan Rachel. Akun tanpa identitas inidisebut juga dengan akun palsu (fake account) dimana akun palsu ini diidentifikasi dari tidak dicantumkannya identitas asli pada rincian profil akun Instagramnya, seperti foto profil, username, keterangan atau biografi. Suatu akun palsu juga biasanya memiliki sedikit pengikut (followers) dan tidak memiliki unggahan atau mengunci akunnya. Umumnya, akun palsu ini digunakan untuk menutupi identitas pemiliknya. 


\section{DAFTAR PUSTAKA}

Armstrong, M. I., Birnie-Lefcovitch, S., \& Ungar, M. T. (2005). Pathways between social support, family well being, quality of parenting, and child resilience: What we know. Journal of Child and Family Studies, 14(2), 269-281.

Bornstein, M. H. (2012). Cultural Approaches to Parenting. Parenting, 12(2-3), 212-221.

Cabotaje, A. (2018). Why Mom Shaming Happens - and How to Shut It Down., diakses 29 Maret 2019, dari https://rightasrain.uwmedicine.org/life/parenthood/mom-shaming

DiMaggio, D., \& Cernigliaro, J. (2019). Baby's First Tooth: 7 Facts Parents Should Know., diakses 3 Februari 2020, dari https://www.healthychildren.org/English/agesstages/baby/teething-tooth-care/Pages/Babys-First-Tooth-Facts-Parents-Should-Know.aspx

Farasya, T. (2020). Belajar Jadi Ibu Bareng Rachel Vennya., diakses 24 Maret 2020, dari Youtube. https://www.youtube.com/watch?v=_pKSyabSRCo

Jax, C. (2017). Facts About Human Growth \& Development in Early Childhood., diakses 3 Februari 2020, dari https://www.hellomotherhood.com/article/1005793-human-growthdevelopment-early-childhood/

Klass, P., \& Damour, L. (2017). How to Be a Modern Parent., diakses 31 Maret 2020, dari https://www.nytimes.com/guides/well/guide-to-modern-parenting

Lane, K. (2017). The History Of Mom-Shaming Celebrities Is Already Too Long., diakses 24 Mei 2019, dari https://www.romper.com/p/the-history-of-mom-shaming-celebrities-is-alreadytoo-long-2919500

Lazarus, S. (2015). 7 Modern Parenting Methods., diakses 24 Mei 2019, dari https://www.babygaga.com/7-modern-parenting-methods/

Lupton, D., Pedersen, S., \& Thomas, G. M. (2016). Parenting and Digital Media: From the Early Web to Contemporary Digital Society. Sociology Compass, 10(8), 730-743.

McDaniel, B. T., Coyne, S. M., \& Holmes, E. K. (2012). New mothers and media use: Associations between blogging, social networking, and maternal well-being. Maternal and Child Health Journal, 16(7), 1509-1517.

Nagesh, A. (2019). Buteyko: Why Indonesia singer Andien sleeps with tape on her mouth., diakses 16 Januari 2020, dari https://www.bbc.com/news/world-asia-48951583

Narvaez, D. F. (2013). New Moms Need Social Support., diakses 16 Maret 2020, dari https://www.psychologytoday.com/intl/blog/moral-landscapes/201301/new-moms-needsocial-support

Ngai, F. W., Chan, S. W. C., \& Holroyd, E. (2012). Maternal coping during early motherhood among first-time Chinese mothers. Journal of Health Psychology, 17(2), 189-196.

O'Brien Hallstein, D. L. (2011). She Gives Birth, She's Wearing a Bikini: Mobilizing the Postpregnant Celebrity Mom Body to Manage the Post-Second Wave Crisis in Femininity. Women's Studies in Communication, 34(2), 111-138.

Preidt, R. (2017). “Mommy-shaming” is common, survey reveals., diakses 24 Maret 2019, dari https://www.cbsnews.com/news/mommy-shaming-is-common-parenting-poll-reveals/ 
Prikhidko, A., \& Swank, J. M. (2018). Motherhood Experiences and Expectations: A Qualitative Exploration of Mothers of Toddlers. Family Journal, 26(3), 278-284.

Tran, T. T. Q., Admiraal, W., \& Saab, N. (2017). Cultural Distance in the Workplace: Differences in Work-Related Attitudes between Vietnamese Employees and Western Employers. International Journal of Business and Management, 12(10), 91.

Ulfah, S. (2019). Eksklusif: Andien Aisyah Blak-Blakan Soal Cyber Bullying yang Dialami Millennial Mama., diakses 9 Maret 2020, dari https://www.popmama.com/life/health/sarrah-ulfah/andien-aisyah-bicara-blak-blakan-soalcyber-bullying-pada-mama-muda/full

Verswijvel, K., Walrave, M., Hardies, K., \& Heriman, W. (2019). Sharenting, is it a good or a bad thing? Understanding how adolescents think and feel about sharenting on social network sites. Children and Youth Services Review.

Villines, Z. (2017). Study Explores How 'Mom Shaming' Affects Mothers' Parenting., diakses 24 Maret 2019, dari https://www.goodtherapy.org/blog/study-explores-how-mom-shamingaffects-mothers-parenting-0703171 